\section{Lingual Lipase in Cystic Fibrosis Quantitation of Enzyme Activity in the Upper Small Intestine of Patients with Exocrine Pancreatic Insufficiency}

Cynthia K. Abrams, Margit Hamosh, Van S. Hubbard, Sudhir K. Dutta, and Paul Hamosh

Department of Pediatrics and Department of Physiology and Biophysics, Georgetown University Medical Center, Washington, DC 20007; Pediatric Metabolism Branch, National Institute of Arthritis, Diabetes, Digestive and Kidney Diseases, National Institutes of Health, Bethesda, Maryland 20205; Department of Medicine, Division of Gastroenterology, University of Maryland Hospital and Veterans Administration Medical Center, Baltimore, Maryland 21201 bstract. We have measured the level of lingual lipase activity in gastric and duodenal aspirates of five patients with cystic fibrosis (CF) and pancreatic insufficiency. Lingual lipase activity (measured in vitro by the hydrolysis of long-chain triglyceride, $\operatorname{tri}-\left[{ }^{3} \mathrm{H}\right]$ olein, at $\mathrm{pH} 4.2$ and expressed in nanomoles FFA released per milliliter aspirate per minute) and $\mathrm{pH}$ in gastric and duodenal aspirates were measured at 10 -min intervals during a 30-min basal period and at 15-min intervals during a 2-h period after the ingestion of a test meal. In gastric aspirates, lingual lipase activity decreased from basal levels of $200 \pm 34$ nmol FFA released per milliliter per minute (similar to values reported previously in normal subjects

This study was presented in part at the National Meeting of the American Federation for Clinical Research, Washington, DC, May 1982 and at the Annual Meeting of the American Gastroenterology Association, Chicago, IL, May 1982 and was published in abstract form (1982. Clin. Res. 30:279a; 1982. Gastroenterology. 82:1047a).

Parts of this work are derived from a dissertation to be submitted to the Graduate School, University of Maryland, by Cynthia K. Abrams in partial fulfillment of the requirements for the Ph.D. degree in Nutritional Sciences.

Address all correspondence to Dr. M. Hamosh, Department of Pediatrics, Georgetown University Medical Center, Washington DC, 20007.

Received for publication 28 April 1983 and in revised form 11 October 1983.

J. Clin. Invest.

(C) The American Society for Clinical Investigation, Inc. 0021-9738/84/02/0374/09

Volume 73, February 1984, 374-382
(Hamosh M., H. L. Klaeveman, R. O. Wolf, and R. O. Scow, 1975, J. Clin. Invest., 55:908-913) to 79 $\pm 15 \mathrm{nmol}$ FFA $/ \mathrm{ml}$ per min during the first postprandial hour and returned to basal levels during the second postprandial hour, (206 $\pm 39 \mathrm{nmol}$ FFA/ml per min). Duodenal aspirates, obtained during basal conditions, had lingual lipase activity similar to that in the stomach, $178 \pm 63 \mathrm{nmol}$ FFA/ml per min. Enzyme activity levels were $56 \pm 14$ and $113 \pm 29$ during the first and second postprandial hours. Measurements of total lipase activity delivered to the ligament of Treitz showed that lingual lipase amounted to $91.22 \pm 4.06 \%$ of the total lipase activity in the upper small intestine during the 150 -min study period. The basal and postprandial gastric $\mathrm{pH}$ levels in the five CF patients studied $(3.2 \pm 0.44,4.0 \pm 0.16$, and $4.4 \pm 0.4$ for basal and first and second postprandial hours, respectively) did not differ from previously reported values for normal subjects. The $\mathrm{pH}$ of duodenal aspirates was however significantly lower $(P<0.001)$ in CF patients, both under basal conditions $(5.0 \pm 0.26)$ and during the first and second postprandial hours ( $4.9 \pm 0.13$ and $4.4 \pm 0.36$, respectively), than in normal subjects. The low postprandial duodenal $\mathrm{pH}$ enables lingual lipase to act not only in the stomach but to continue the hydrolysis of dietary fat in the upper small intestine of CF patients. The data presented show that lingual lipase remains fully active in $\mathrm{CF}$ and accounts for $>90 \%$ of total lipase activity in the upper small intestine. We suggest that, because of low intestinal $\mathrm{pH}$ in $\mathrm{CF}$, enzyme replacement therapy containing lingual lipase could improve fat absorption in CF patients to a greater extent than the pancreatic preparations now in use. 


\section{Introduction}

Exocrine pancreatic insufficiency, resulting in steatorrhea, is found in at least $85 \%$ of cystic fibrosis $(C F)^{1}$ patients (1-3). However, the degree to which fat is absorbed by these patients varies, and even when pancreatic lipase activity is completely absent, dietary fat is absorbed. Ross (4) found fat absorption to be between 26 and $81 \%$ in a group of children with CF, although most of them did not have detectable pancreatic lipase activity. These findings were supported by Muller et al. (5), who reported $50 \%$ absorption of dietary fat in a patient with congenital absence of pancreatic lipase activity, and by Lapey et al. (6) who found $>50 \%$ fat absorption in 15 patients with exocrine pancreatic insufficiency secondary to $\mathrm{CF}$, without any oral enzyme supplementation. Ross and Sammons (7) have postulated the presence of compensatory lipolytic activity in pancreatic insufficiency, but were unable to find the source of that activity.

We propose that lingual lipase (8) provides the extrapancreatic lipolytic activity seen in CF. Lingual lipase, an enzyme secreted from lingual serous glands $(8,9)$, hydrolyzes dietary triglycerides at $\mathrm{pH}$ 3.0-6.5 and thus initiates the digestion of fat in the stomach. Since the lipase in preparations of human $(8)$ and rat $(9,10)$ lingual serous glands, as well as in esophageal (11) and gastric aspirates (11-13) of healthy adults and infants (14-16), has similar characteristics (molecular weight, substrate specificity, pH optimum) and because only very low lipase activity has been reported in rat gastric mucosa (9), we assume that lingual lipase is the main digestive enzyme in the stomach. This lipase (8-16) differs from pancreatic lipase (17) in that it is relatively acid resistant, does not require bile salts for activity, and has a low pH optimum. Recent animal studies have shown that hydrolysis of fat in the stomach is essential for normal fat absorption, even under conditions of normal pancreatic function. Several studies have demonstrated that after diversion of oral secretions by means of an esophageal fistula, there is not only a marked fall in intragastric lipolysis (9), but also a decrease in intestinal fat digestion as well as a rise in fat and bile salt excretion (18). It appears that fat digestion in the stomach may be a much more important process in conditions of physiologic or pathologic pancreatic insufficiency. Adequate fat absorption in the newborn is directly related to high levels of lingual lipase activity $(14,15)$ and gastric lipolysis $(14,16)$, suggesting that the latter can successfully compensate for the low pancreatic lipase activity (19-21) and bile acid levels (21-25) of early infancy. Lingual lipase could play a similar role in CF, a disease characterized by impaired pancreatic acinar function (26) (and thus absence of pancreatic enzymes), impaired pancreatic ductular function (leading to impaired water and bicarbonate secretion [27]), as well as decreased duodenal bile acid concentration (28-33). Furthermore, because of low bicarbonate secretion, the low

1. Abbreviations used in this paper: $\mathrm{CF}$, cystic fibrosis; PEG, polyethylene glycol. duodenal $\mathrm{pH}$ in the postprandial phase (4-6) would be compatible with continued activity of lingual lipase.

The aim of this study was to $(a)$ measure intraluminal $\mathrm{pH}$ in the stomach and duodenum in basal and postprandial conditions; $(b)$ measure lingual lipase activity in the stomach and duodenum in the basal and postprandial period; and finally $(c)$ to quantitate the contribution of lingual lipase activity to the total lipolytic activity in the duodenum.

\section{Methods}

Five male $C F$ patients with pancreatic insufficiency participated in this study. The study was approved by the Institutional Review Committees of the National Institutes of Health, University of Maryland Hospital and Georgetown University Medical Center. Informed consent was obtained from all patients before the study.

Adult male patients (age 21-29 yr) were selected because of the availability of data from control subjects $(11,34)$ and from subjects with pancreatic insufficiency secondary to chronic alcoholic pancreatitis (34) who had been studied previously. The diagnosis of CF was based on clinical evaluation and a sweat chloride $>60 \mathrm{meq} /$ liter. Pancreatic insufficiency was previously documented by the absence of pancreatic digestive enzymes (trypsin, chymotrypsin, lipase, and amylase) in duodenal aspirates and abnormal quantitative fecal fat in all patients. All patients had evidence of pulmonary disease and their NIH clinical score (35) ranged from 50 to 88 . Three of the five patients were receiving continuous oral antibiotic coverage for treatment of their respiratory disease. All subjects had been receiving pancreatic extracts, vitamin $\mathrm{E}$ (Aquasol E), and multivitamins. The brand of pancreatic extracts used by each patient was different and the dosage used was based on control of their gastrointestinal symptomatology as judged by the patients or their referring physicians. No change in the subjects' clinical status or medications prescribed occurred during the study period. The subjects were electively hospitalized at the National Institutes of Health Clinical Center during the time the study was conducted. Clinical data regarding the subjects are given in Table I.

Collection of specimens. After an overnight fast, the patients were asked to swallow a triple-lumen polyvinyl tube (each lumen $1.2 \mathrm{~mm}$ i.d.) with a mercury bag at the tip. The polyvinyl tube was placed under fluoroscopic control, in such a way that the perfusion site was located at the ampulla of Vater, and the distal opening for duodenal sample aspiration at the ligament of Treitz. The most proximal opening was placed in the antrum for aspiration of gastric samples. After proper placement of the tube, the duodenum was perfused with normal saline containing $\left[{ }^{14} \mathrm{C}\right]$ polyethylene glycol (PEG) $(10 \mu \mathrm{Ci} /$ liter, New England Nuclear, Boston, MA) at a rate of $2 \mathrm{ml} / \mathrm{min}$. Before collection of baseline samples, the duodenum was perfused for $30 \mathrm{~min}$ for equilibration. Base-line samples were aspirated from the stomach and duodenum at 10-min intervals for half an hour. The patients were then asked to ingest a standardized test meal. The meal consisted of $8 \mathrm{oz}$ orange juice, $8 \mathrm{oz}$ vanilla Ensure (Mead Johnson Co., Evansville, IL), and 4 oz vanilla ice cream, and contained 500 calories, $59 \%$ carbohydrate, $30 \%$ fat, and $11 \%$ protein. The test meal was eaten without supplemental pancreatic enzyme administration. Postprandial specimens were sampled at 15 -min intervals for $2 \mathrm{~h}$.

Immediately after collection of each sample, $\mathrm{pH}$ was measured by glass electrode (pH meter, Radiometer, Copenhagen), and the specimens 
were transferred to polypropylene tubes, capped, and kept on dry ice until transfer to the laboratory. All specimens were stored at $-70^{\circ} \mathrm{C}$ until assay. Under these storage conditions, lipolytic activity is stable for years $(15,36)$.

Assay of lipase activity. The specimens were thawed rapidly and the $\mathrm{pH}$ measured again with the aid of pH paper. The lipolytic activity in all specimens was measured using a long-chain triglyceride substrate, tri- $\left.-{ }^{3} \mathrm{H}\right]$ olein). A stable preparation of the triglyceride was made by emulsification of the labeled and carrier triolein $(200 \mu \mathrm{mol})$ with phosphatidylcholine $(15 \mu \mathrm{mol})$ and anhydrous glycerol $(3.3 \mathrm{ml})$ as described in detail elsewhere (37). The assay mixture contained in a final volume of $200 \mu \mathrm{l}: 1 \mu \mathrm{mol}$ of labeled triglyceride, $15 \mu \mathrm{mol}$ of sodium citrate buffer, $\mathrm{pH} 4.2$ or Tris- $\mathrm{HCl} \mathrm{pH} 8.1,5.6 \mathrm{mg}$ of bovine plasma albumin (fraction V, Armour Pharmaceutical Co., Tarrytown, NY, lot N 50402) and 50 $\mu \mathrm{l}$ gastric or duodenal aspirate. Incubation was for $30 \mathrm{~min}$ at $37^{\circ} \mathrm{C}$ in a Dubnoff shaking bath. The reaction was stopped by the addition of $3.25 \mathrm{ml}$ of a mixture of methanol/chloroform/heptane (1.41:1.25:1, vol/ $\mathrm{vol} / \mathrm{vol}$ ). FFA were separated from glycerides by the addition of 1.05

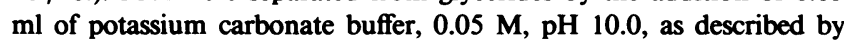
Belfrage and Vaughan (38). Aliquots of $0.5 \mathrm{ml}$ from the aqueous phase were transferred to $5.0 \mathrm{ml}$ Aquasure scintillation fluid (New England Nuclear) and the radioactivity was measured in a Beckman model LS 7500 scintillation spectrometer (Beckman Instruments, Inc., Fullerton, CA), using internal standards for quench correction.

Of total FFA, $70-80 \%$ were present in the alkaline upper phase. Mixtures of nonradioactive triglyceride emulsion and $\left[{ }^{3} \mathrm{H}\right]$ oleic acid were used to determine the partition coefficient of FFA in the two phases. The partition of FFA between the nonaqueous and aqueous phases was not affected by the following changes in the reaction mixture: type of buffer, $\mathrm{pH}$ of medium, or albumin concentration (10). Partial glycerides (mono- and diglycerides) are retained in the nonaqueous phase and do not interfere with the quantitation of FFA (10).

The triglyceride concentration of the substrate emulsion was quantitated by the hydroxamic acid method of Rapport and Alonzo (39).

Lipase activity was expressed as nanomoles of FFA produced per milliliter aspirate per minute.

Total lipase activity delivered to the ligament of Treitz was calculated according to Malagelada et al. (40), as follows:

Lipase $(\mathrm{IU} / 15 \mathrm{~min})=\left(\right.$ Concentration of $\left[{ }^{14} \mathrm{C}\right] \mathrm{PEG}$ in infusate $) /$ (Concentration of $\left[{ }^{14} \mathrm{C}\right] P E G$ in aspirate)

$\times$ lipase activity of duodenal aspirate $\times$ collection time (min) $X$ infusion rate $(\mathrm{ml} / \mathrm{min})$.

Because an earlier report (42) indicated that PEG in the range of $1-5 \mathrm{mg} / \mathrm{ml}$ inhibits the activity of pancreatic lipase (0-50\% inhibition), we have tested the effect of PEG on lingual lipase. PEG was added to purified rat lingual lipase and to human gastric and duodenal aspirates collected without the marker and lipase activity was measured in the assay system described above. These tests showed that PEG does not inhibit lingual lipase activity in the range reported to affect pancreatic lipase ( $1-5 \mathrm{mg} / \mathrm{ml}$ PEG).

Statistical analysis was conducted using the $t$ test (41).

\section{Results}

The clinical data for the five CF patients studied are given in Table I. The diagnosis of cystic fibrosis was made at birth (one patient), in infancy (three patients), or at the age of $13 \mathrm{yr}$ (one patient). Pancreatic insufficiency was documented by absence of pancreatic enzymes in duodenal aspirates and steatorrhea in
Table I. Clinical Data of CF Patients

\begin{tabular}{lccccc}
\hline Patient No. & 1 & 2 & 3 & 4 & 5 \\
Age $(\mathrm{yr})$ & 22 & 29 & 28 & 22 & 23 \\
Height $(\mathrm{cm})$ & 182 & 173 & 178 & 172 & 182 \\
$\begin{array}{l}\text { Weight }(\mathrm{kg}) \\
\text { NIH clinical score (35) }\end{array}$ & 55.0 & 72.8 & 52.8 & 59.0 & 63.9 \\
$\begin{array}{c}\text { Fat excretion* } \\
(\% \text { of fat intake) }\end{array}$ & 8.4 & 27.6 & 45.1 & 28.4 & 30.4 \\
$\begin{array}{c}\text { Serum cholesterolf } \\
(m g / \text { dl) }\end{array}$ & 88 & 160 & 96 & 114 & 60 \\
$\begin{array}{c}\text { Serum carotene§ } \\
\quad(\mu g / d l)\end{array}$ & 22 & 31 & 26 & 24 & 17 \\
$\begin{array}{c}\text { Age at time of CF } \\
\text { diagnosis }\end{array}$ & 13 yr & $8 \mathrm{mo}$ & $9 \mathrm{mo}$ & $2 \mathrm{mo}$ & Birth \\
\hline
\end{tabular}

* Fat excretion was quantitated while the patients received 4 Cotazyme capsules (Organon Pharmaceuticals, W. Orange, NJ: 8,000 USP lipase U/capsule) per meal. Fat intake (grams per day) was 237,115 , 150,240 , and 235 for patients $1-5$, respectively.

$\ddagger$ Range of normal values: $163-263 \mathrm{mg} / \mathrm{dl}$.

$\S$ Range of normal values: $50-300 \mu \mathrm{g} / \mathrm{dl}$.

all patients. A 72-h stool collection (defined by excretion of stool markers given $72 \mathrm{~h}$ apart) for quantitation of fecal fat while on an ad lib. but recorded diet was performed and showed various degrees of fat malabsorption (Table I). Steatorrhea was present in all patients, even while they were receiving four Cotazyme capsules/meal.

pH of gastric aspirates in CF patients. Data for the baseline and postprandial $\mathrm{pH}$ in gastric aspirates are given in Fig. $1 A$ and Table II. There was wide variation in the $\mathrm{pH}$ values during the $30-\mathrm{min}$ base-line collection period. The $\mathrm{pH}$ range was narrower during the first hour after ingestion of the test meal (pH 3.2-5.0) and widened again during the second postprandial hour (pH 1.3-5.5). The mean basal $\mathrm{pH}$ in gastric aspirates of CF patients $(3.2 \pm 0.44)$ was not different from that previously reported by one of us (Dr. M. Hamosh) for 10 healthy, age-matched, volunteers ( $\mathrm{pH} 3.5 \pm 0.26)(11)$. The postprandial $\mathrm{pH}$ of the gastric aspirates of the five patients (mean value for the first hour after the meal 4.0 \pm 0.16 ) did also not differ from the postprandial gastric pH of normal controls (4.4 \pm 0.4$)$ (11).

pH of duodenal aspirates in CF patients. The basal duodenal pH was significantly $(P<0.001)$ lower (range 3.0-6.7) in the five CF patients studied (Fig. $1 B$ and Table II) than previously reported by one of us (Dr. S. K. Dutta) for seven normal subjects (pH range 6.2-7.5) (34). The postprandial duodenal pH level was also significantly lower in CF patients than in normal subjects. In four patients, the duodenal $\mathrm{pH}$ remained $<5.0$ throughout the 2-h postprandial period studied, whereas in the fifth patient, the duodenal $\mathrm{pH}$ fluctuated between 5.0 and 5.4 and only one specimen had a pH of 6.2. For most of the postprandial period, the duodenal $\mathrm{pH}$ in control subjects was between 5.5 and $7.2(34)$. The mean duodenal $\mathrm{pH}$ values during basal, and 


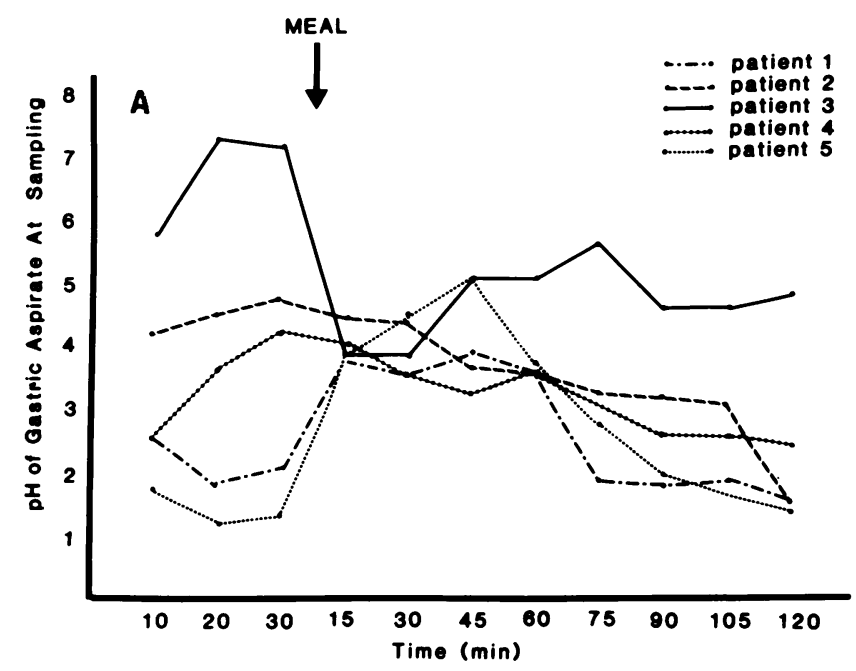

Gastric Aspirate Collection Sequence

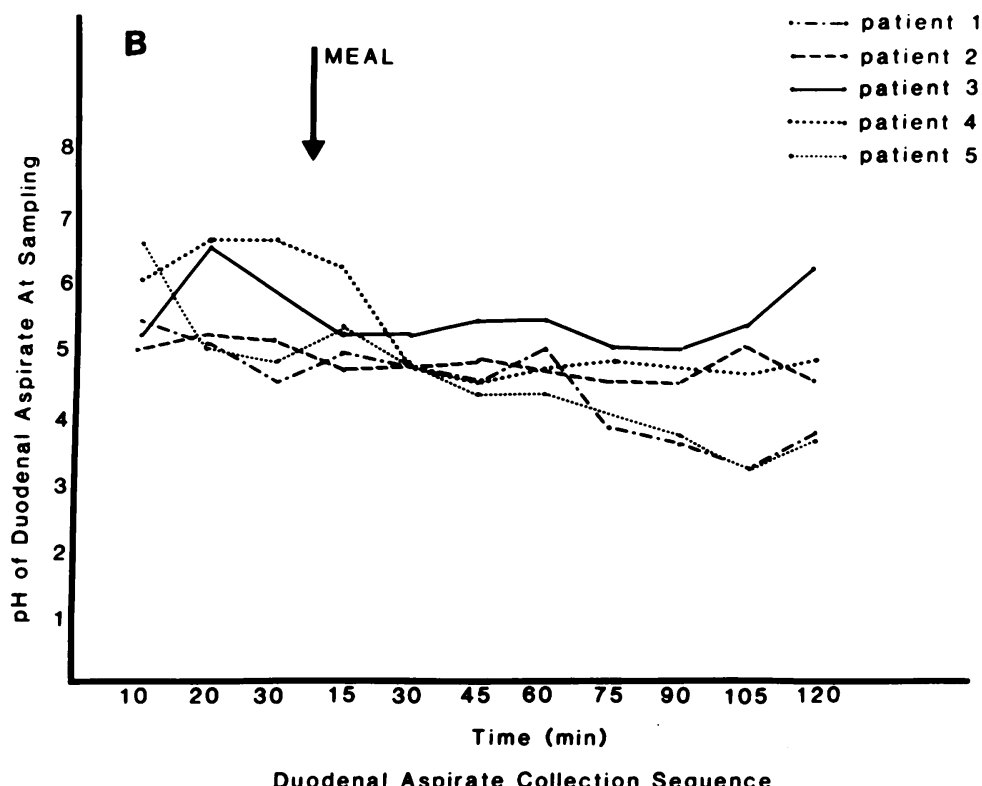

Figure 1. $(A) \mathrm{pH}$ of gastric aspirates in $\mathrm{CF}$. The $\mathrm{pH}$ of gastric aspirates was measured at 10 -min intervals for $30 \mathrm{~min}$ before and at 15-min intervals for $120 \mathrm{~min}$ after ingestion of a test meal of 500 calories containing $59 \%$ carbohydrate, $30 \%$ fat, and $11 \%$ protein. Data for five patients. $(B) \mathrm{pH}$ of the luminal contents from the upper small intestine in CF. Basal (30-min at 10-min intervals), and postprandial $\mathrm{pH}$ measurements (at 15-min intervals for 120 min after ingesting a test meal) in the duodenal aspirates of five CF patients. the first and second postprandial hours were significantly lower $(P<0.001)$ in CF patients than in control subjects. The duodenal $\mathrm{pH}$ remained in the acid range for the entire $2 \mathrm{~h}$ following ingestion of the meal.

Relationship between $\mathrm{pH}$ and lingual lipase activity in gastric and duodenal aspirates. The low $\mathrm{pH}$ of the duodenal aspirates suggested that lingual lipase, an enzyme with a pH optimum of 3.0-6.5, might remain active in the upper small intestine in $\mathrm{CF}$. The relationship between $\mathrm{pH}$ and lingual lipase activity in all the specimens studied, gastric as well as duodenal aspirates, is shown in Fig. 2. The pH of most of the aspirates was in the range of 3.0-6.0, thus coinciding with the optimal $\mathrm{pH}$ range of lingual lipase activity. The data in Fig. 2 show that there was no linear relationship between lipase activity and the $\mathrm{pH}$ of the aspirate and that aspirates with a $\mathrm{pH}<2.0$ had only very low or no lipase activity. There was no significant difference in the level of lipase activity in the gastric or duodenal aspirates.

Lingual lipase activity in the stomach and duodenum. Basal lipase activity levels in the stomach of five CF patients (Table II) were similar $(200 \pm 34 \mathrm{nmol}$ FFA released/ml aspirate per min) to values previously reported by us for normal subjects $(197 \pm 31,[11])$. Lingual lipase activity in gastric aspirates decreased significantly $(P<0.05)$ during the first hour after ingestion of the test meal (mean $79 \pm 15 \mathrm{nmol}$ FFA released/ml aspirate per $\min$ ) and returned to basal levels during the second postprandial hour (206 \pm 39$)$. The decrease in enzyme activity after ingestion of the meal is probably due to dilution of gastric contents by the meal and to increased gastric secretions. It is 
Table II. pH and Lingual Lipase Activity* in Gastric and Duodenal Aspirates in $C F$

\begin{tabular}{|c|c|c|c|c|}
\hline & \multicolumn{2}{|c|}{ Gastric aspirate } & \multicolumn{2}{|c|}{ Duodenal aspirate } \\
\hline & $\mathrm{pH}$ & $\begin{array}{l}\text { Lingual lipase } \\
\text { activity }\end{array}$ & $\mathrm{pH}$ & $\begin{array}{l}\text { Lingual lipase } \\
\text { activity }\end{array}$ \\
\hline Basal (fasting) $\ddagger$ & $\begin{array}{l}3.2 \pm 0.44 \\
(1.2-7.2)\end{array}$ & $\begin{array}{l}200 \pm 34 \\
(0-572)\end{array}$ & $\begin{array}{l}5.0 \pm 0.26 \\
(3.0-6.9)\end{array}$ & $\begin{array}{l}178 \pm 63 \\
(0-534)\end{array}$ \\
\hline \multicolumn{5}{|l|}{ Postprandial§ } \\
\hline $1 \mathrm{st} \mathrm{h}$ & $\begin{array}{l}4.0 \pm 0.16 \\
(3.2-5.0)\end{array}$ & $\begin{array}{r}79 \pm 15 \\
(0-219)\end{array}$ & $\begin{array}{l}4.9 \pm 0.13 \\
(4.3-6.2)\end{array}$ & $\begin{array}{r}56 \pm 14 \\
(0-137)\end{array}$ \\
\hline 2nd $h$ & $\begin{array}{l}2.7 \pm 0.58 \\
(1.3-5.5)\end{array}$ & $\begin{array}{l}206 \pm 39 \\
(0-457)\end{array}$ & $\begin{array}{l}4.4 \pm 0.36 \\
(3.2-6.2)\end{array}$ & $\begin{array}{l}113 \pm 29 \\
(5-269)\end{array}$ \\
\hline
\end{tabular}

* Lingual lipase activity; nanomoles FFA released per milliliter aspirate per minute.

$\ddagger 15-16$-h fast.

$\S 1$ st and 2 nd $\mathrm{h}$ after ingestion of test meal ( 500 calories, $59 \%$ carbohydrate, $30 \%$ fat, $11 \%$ protein). The data are mean \pm SEM (range of values in parenthesis) of five patients studied.

also possible that the lipase binds rapidly to the food in the stomach and that less remains free in gastric juice. Return to basal levels during the second postprandial hour suggests con-

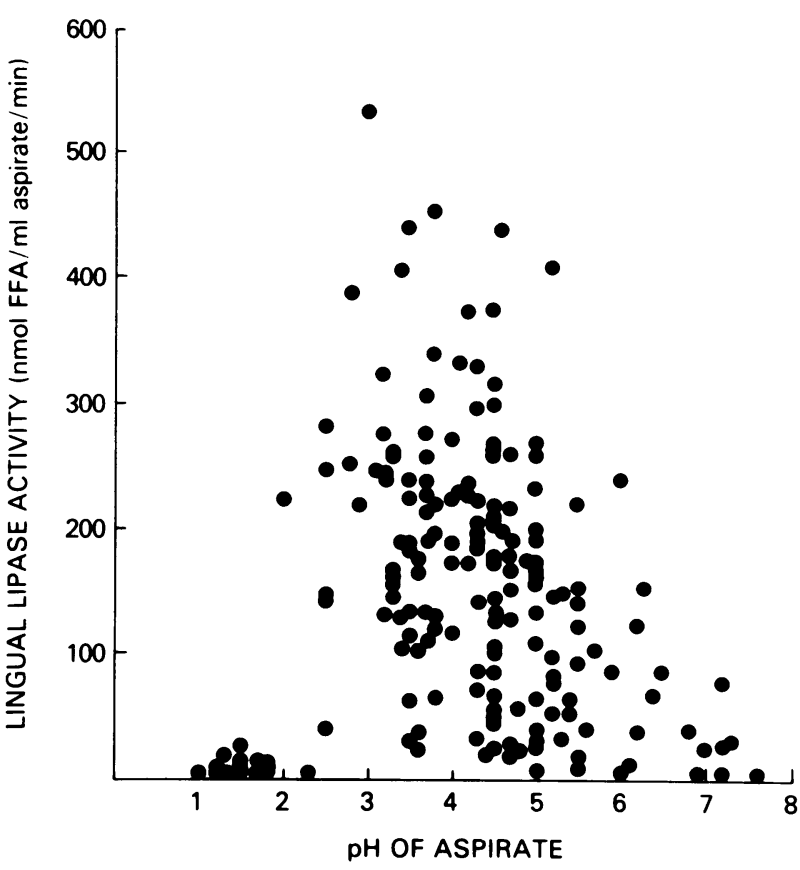

Figure 2. Relationship between the pH of gastric and duodenal aspirates and the level of lingual lipase activity. Each dot represents the level of lingual lipase activity (ordinate) and $\mathrm{pH}$ (abscissa) for each specimen of gastric or duodenal aspirate from CF patients. tinuous enzyme secretion, probably independent of oral stimulation by ingestion of food.

Basal lingual lipase activity levels in the duodenum of CF patients (178 \pm 63 ) were similar to fasting enzyme activity levels in the stomach (Table II). Lingual lipase activity was present in duodenal aspirates of all five patients throughout the 2-h postprandial period studied. Although enzyme activity appeared to decrease after eating, the difference between basal and postprandial activity levels was not statistically significant. The data suggest that, because of the persistent low postprandial duodenal pH (Fig. 2 and Table II), lingual lipase continues to be active for several hours after ingestion of food in the upper small intestine of CF patients.

Quantitation of total lipase activity delivered to the ligament of Treitz under basal and postprandial conditions. The total amount of lipase delivered to the ligament of Treitz was quantitated with the aid of ${ }^{14} \mathrm{C}$-labeled PEG $(10 \mu \mathrm{Ci} /$ liter) infused at a rate of $2 \mathrm{ml} / \mathrm{min}$ (40). All specimens of duodenal aspirate were analyzed for lingual lipase (assay at pH 4.2) and nonlingual lipase (assay at pH 8.1 with and without $4 \mathrm{mM}$ sodium taurocholate) for quantitation of the lipase activity delivered to the duodenum under basal and postprandial conditions. The data are presented in Table III and Fig. 3. Lingual lipase amounted to $91.22 \pm 4.06 \%$ of the total lipase activity delivered to the ligament of Treitz during the 150-min study period. Only one patient had lingual lipase activity of $<90 \%$ of total lipolytic activity. There was no difference between basal and postprandial sampling periods, or between the first or second hour after ingestion of the test meal (Table III). At all times tested, lingual lipase activity was $>90 \%$ of total lipase in the upper small intestine.

Table III. Basal and Postprandial Levels of Lingual Lipase Activity Delivered to the Ligament of Treitz

\begin{tabular}{llllllll} 
Patient No. & 1 & 2 & 3 & 4 & 5 & Mean \pm SE \\
\hline
\end{tabular}

Lingual lipase activity percent of total lipase activity

\begin{tabular}{|c|c|c|c|c|c|c|}
\hline $\begin{array}{l}\text { Total collection } \\
\text { period }(150 \mathrm{~min})\end{array}$ & 96.6 & 93.8 & 92.0 & 97.0 & 76.7 & $91.22 \pm 4.06$ \\
\hline Basal (30 min) & 97.5 & 96.5 & 91.9 & 98.9 & 88.8 & $94.72 \pm 1.4$ \\
\hline \multicolumn{7}{|l|}{ Postprandial } \\
\hline 1st h & 96.3 & 98.4 & 89.5 & 96.3 & 78.4 & $91.8 \pm 4.0$ \\
\hline \multirow[t]{2}{*}{ 2nd $h$} & 96.5 & 87.5 & 96.5 & 97.8 & 73.2 & $90.3 \pm 4.6$ \\
\hline & \multicolumn{6}{|c|}{$\begin{array}{c}\text { Percent of lingual lipase activity delivered to ligament } \\
\text { of Treitz during sampling interval }\end{array}$} \\
\hline Basal (30 min) & 11.9 & 40.8 & 72.8 & 25.3 & 14.2 & $33.00 \pm 12.8$ \\
\hline lst h & 59.0 & 26.0 & 15.8 & 50.9 & 36.8 & $37.70 \pm 8.6$ \\
\hline 2nd $h$ & 29.9 & 32.9 & 11.3 & 23.7 & 48.9 & $29.15 \pm 7.2$ \\
\hline
\end{tabular}

* Lingual lipase activity percentage of total lipase activity delivered to the ligament of Treitz during the entire collection period (150 min: 30 min basal, 120 min after test meal). 


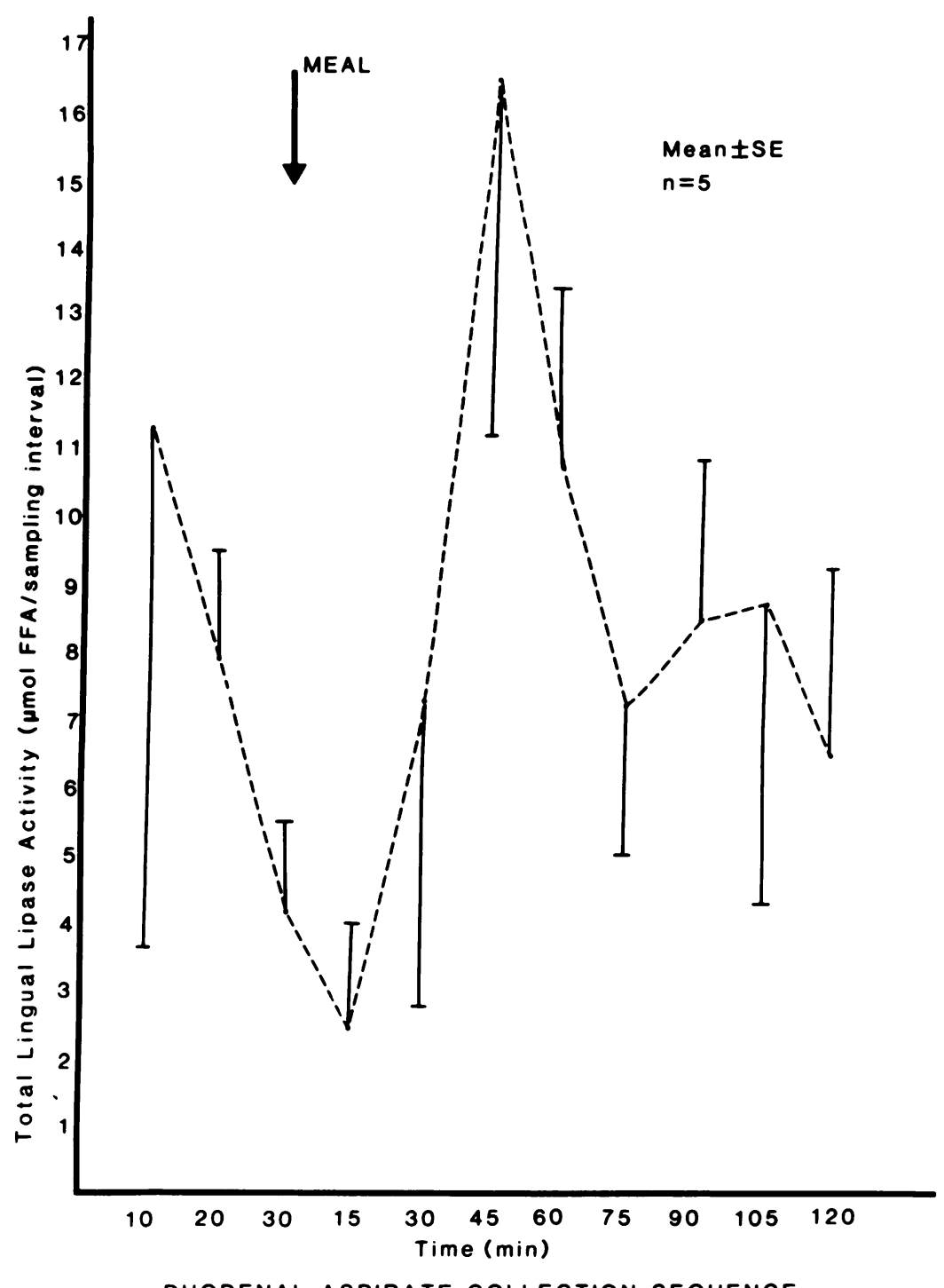

Figure 3. Quantitation of lingual lipase activity delivered to the ligament of Treitz during basal (first 30 min after an overnight fast) and postprandial conditions (during $120 \mathrm{~min}$ after a test meal) in CF patients.
Although the mean values for the amounts of lingual lipase delivered to the duodenum were similar during the initial 30 min basal study period, during the first hour after ingestion of the test meal and during the second postprandial hour, the individual values fluctuated widely (Table III). Thus, while in patients 1 and 5 the amounts of lipase activity delivered to the ligament of Treitz during the basal period were 11.9 and $14.2 \%$, respectively, in patient $3,72.8 \%$ of lipase activity was delivered to the duodenum during this initial study period.

\section{Discussion}

The data presented suggest that lingual lipase might be responsible for the hydrolysis of dietary fat in CF patients with exocrine pancreatic insufficiency. The changes in the intestinal milieu in $\mathrm{CF}$, low postprandial pH (Fig. $1 B$ and Table II), and low con- centration of bile salts (28-33) actually enable lingual lipase to act not only in the stomach (its normal site of action) but to continue the hydrolysis of dietary fat in the duodenum. High levels of lingual lipase activity in the stomach and in the duodenum during basal as well as postprandial conditions (Table II and III, Fig. 3), suggest that this enzyme might hydrolyze as much as $40-70 \%$ of dietary fat, the amount absorbed by patients who do not receive pancreatic enzyme supplements (6).

There is good evidence from both human and animal studies that as much as $70 \%$ of dietary fat is absorbed in the absence of pancreatic lipase activity. Several earlier studies have shown that children with congenital or acquired absence of pancreatic lipase $(43,44)$ absorb as much as $70 \%$ of ingested fat. Detailed animal studies to establish the extent of fat digestion and absorption in the absence of pancreatic secretions were carried out in calves by Gooden and Lascelles (45). Their studies show 
that $47 \%$ of milk fat entered the ileum digested to partial glycerides and FFA, compared with $60 \%$ in intact calves. Furthermore, $70 \%$ of long-chain triglyceride fatty acids was absorbed in the absence of pancreatic juice. Thus, as much as $70 \%$ of dietary fat can also be absorbed in ruminants lacking pancreatic lipase, the chief compensatory enzyme being pregastric esterase (4648 ), an enzyme of similar origin and characteristics as lingual lipase in man $(8,11,15)$.

Measurements of lingual lipase activity in gastric aspirates, by in vitro assay of hydrolysis of long-chain triglyceride, show similar basal levels of activity in CF patients (Table II) and in age-matched normal subjects (11). A similar comparison of the hydrolysis of tributyrin by the lipase in gastric aspirates, has shown higher lipolytic activity in CF patients than in controls (49). Although the difference between our data and data reported by Roulet et al. (49) could be due to the different substrates used to quantitate lipase activity (triolein vs. tributyrin), it is more likely that the higher activity in the CF group was associated with the significantly lower age than that of the control group. Lingual lipase activity in gastric aspirates is higher at younger age both in man $(11,15)$ and rat $(50,51)$.

The $\mathrm{pH}$ of gastric aspirates during basal and postprandial conditions was similar in the five CF patients studied (Table II, Fig. $1 A$ ) to that of 10 age-matched healthy subjects studied previously (11). Although it is not clear whether CF patients with pancreatic insufficiency have normal (52), hypo- (53) or hypersecretion (54) of gastric acid, the $\mathrm{pH}$ in the stomach of the CF patients studied was in the optimal range for lingual lipase activity $(8,11,15)$. Seldom was the $\mathrm{pH}$ in the stomach $<2.0$ (Fig. $1 \mathrm{~A}$ ). In gastric aspirates with $\mathrm{pH}<2.2$ (as we have previously seen in gastric aspirates of healthy newborn infants [15]), lipase activity was undetectable. We do not yet know the reason for the loss of activity at $\mathrm{pH} 2.0$, i.e., whether it is the result of denaturation of the lipase or of peptic digestion (55) of the enzyme at low $\mathrm{pH}$.

The normal values of basal and postprandial $\mathrm{pH}$ in the stomach of CF patients are in sharp contrast to the significantly lower $\mathrm{pH}$ in the duodenum throughout the entire study period (Fig. $1 B$ and Table II). Earlier studies have shown that secretion of bicarbonate is markedly impaired in children suffering from CF (27). Most of the bicarbonate in pancreatic secretions is secreted by cells lining the pancreatic ducts, and indeed, it has been shown that "ductular activity" is more severely impaired in CF than in exocrine pancreatic insufficiency of other origin (27). There is good evidence that patients with significant exocrine pancreatic disease have an acid $\mathrm{pH}$ in the upper small intestine, under both fasting and postprandial conditions (34), because of impaired ability to neutralize even small levels of acid in the duodenum (56). The present study shows that in $\mathrm{CF}$ patients with pancreatic insufficiency the $\mathrm{pH}$ measured at the ligament of Treitz both before and after a test meal, remains $<5.5$ for most of the test period of $150 \mathrm{~min}$. It was suggested previously (56) that the relatively acidic intraluminal environment in the upper small intestine in pancreatic insufficiency may have significant influence on the absorption of nutrients and drugs. Thus, enhanced folate absorption in patients with pancreatic insufficiency (57) is probably due to the low intraluminal $\mathrm{pH}(<6.0)$, which is optimal for maximal folate uptake (58). The low postprandial $\mathrm{pH}$ in the upper small intestine might also be associated with higher activity of lingual lipase, an enzyme active at pH 3.0-6.5 (Fig. 3, Table III, and reference 59). Our study indeed shows that throughout the 2 -h postprandial period, lingual lipase activity amounted to $>90 \%$ of total lipase activity delivered to the ligament of Treitz in CF patients. A comparison of our data on lingual lipase in CF patients with the data reported for pancreatic lipase in healthy subjects by Di Magno et al. (60) shows that the total amount of lingual lipase delivered to the ligament of Treitz, during the first and second postprandial hours (Fig. 3), amounts to $\sim 25-40 \%$ of the maximal amount of pancreatic lipase released in response to cholecystokinin-pancreozymin stimulation in healthy adults (60).

Although the relationship between lingual lipase activity, hydrolysis of fat, and extent of steatorrhea was not the aim of this study, the data indicate a possible correlation between lingual lipase output and fat absorption: high lipase activity (51 KU/ h) was associated with low fat excretion (8.4\% of intake, patient 1 ), whereas (in patient 3 ) the highest fat excretion $(45.1 \%$ of intake) was associated with the lowest level of lingual lipase $(11.3 \mathrm{KU} / \mathrm{h})$; the other patients had intermediate levels of both lipase activity $(18-20 \mathrm{KU} / \mathrm{h})$ and fat excretion $(27-28 \%$ of intake). The reason for the presence of steatorrhea despite considerable lipolytic activity in these patients, remains to be investigated. Resection of part of the intestine (documented in one patient, but unknown for the other patients) might be one of the reasons. We do not yet know to what extent the enzyme might be active in the duodenum of normal subjects.

In addition to lingual lipase activity, duodenal aspirates of all five patients contained low levels (mean $8.7 \%$ of total activity) of a lipolytic activity with an alkaline pH optimum (Table III). Since the patients have repeatedly been tested for many years and found to be completely deficient of pancreatic lipase, we do not know the nature or origin of the lipolytic activity that we measure at $\mathrm{pH} \mathrm{8.1.} \mathrm{It} \mathrm{is} \mathrm{possible} \mathrm{that} \mathrm{this} \mathrm{lipase} \mathrm{activity} \mathrm{is}$ similar to a lipase described previously in the intestinal mucosa of several species (61-64), and that it remains active in CF. To what extent this lipase might be able to act in the acidic environment of the upper small intestine of $\mathrm{CF}$ patients is not known at present.

Malabsorption in CF patients with pancreatic insufficiency is generally treated by administration of exogenous pancreatic extracts. Several reports suggest, however, that pancreatic enzyme supplements do not normalize fat absorption in CF (65-67). Inactivation in the stomach and low duodenal $\mathrm{pH}$ are the main reasons that only as little as $8 \%$ of the lipase given in pancreatic supplements reaches the ligament of Treitz (65-67). The effectiveness of pancreatic supplements improves after reduction of acid secretion by cimetidine (68-71), but even under these conditions there is marked inactivation of pancreatic lipase (72, 73). Our study suggests that lingual lipase might provide better 
therapy for the prevention of steatorrhea in CF. Lingual lipase supplements would remain fully active in the acid environment of the stomach and intestine and furthermore would not be affected by low levels of bile salts or absence of colipase. Further studies are needed to explore the possibility of treating pancreatic insufficiency with enzyme preparations with high lingual lipase activity.

\section{Acknowledgments}

We thank the patients who participated in this study for their enthusiasm, Dr. Jeffrey Harvey, for the meticulous collection of samples after tube placement, and Ms. Marguerite Starry for secretarial help.

This study was supported by National Institutes of Health grants MA 26641 and HD 10823.

\section{References}

1. Chase, H. P., M. A. Long, and M. H. Lovin. 1979. Cystic fibrosis and malnutrition. J. Pediatr. 95:337-345.

2. di Sant 'Agnese, P. A., and P. B. Davis. 1979. Cystic fibrosis in adults. Am. J. Med. 66:121-132.

3. Jacobs, W., and J. Kanarek. 1981. Cystic fibrosis: as they grow older. Am. J. Gastroenterol. 76:342-346.

4. Ross, C. A. C. 1955. Fat absorption studies in the diagnosis and treatment of pancreatic fibrosis. Arch. Dis. Child. 30:316-321.

5. Muller, D. P. R., J. P. K. McCollum, R. S. Trompeter, and J. T. Harries. 1975. Studies on the mechanism of fat absorption in congenital isolated lipase deficiency. Gut. 16:838. (Abstr.)

6. Lapey, A., J. Kattwinkel, P. A. di Sant 'Agnese, and L. Laster. 1974. Steatorrhea and azotorrhea and their relation to growth and nutrition in adolescents and young adults with cystic fibrosis. J. Pediatr. 84:328-334.

7. Ross, C. A. C., and H. G. Sammons. 1955. Nonpancreatic lipase in children with pancreatic fibrosis. Arch. Dis. Child. 30:428-431.

8. Hamosh, M., and W. A. Burns. 1977. Lipolytic activity of human lingual glands (Ebner). Lab. Invest. 37:606-608.

9. Hamosh, M., and R. O. Scow. 1973. Lingual lipase and its role in the digestion of dietary fat. J. Clin. Invest. 52:88-95.

10. Hamosh, M., D. Ganot, and P. Hamosh. 1979. Rat lingual lipase: characteristics of enzyme activity. J. Biol. Chem. 254:1212112125.

11. Hamosh, M., H. L. Klaeveman, R. O. Wolf, and R. O. Scow. 1975. Pharyngeal lipase and digestion of dietary triglyceride in man. $J$. Clin. Invest. 55:908-913.

12. Cohen, M., G. R. G. Morgan, and A. F. Hofmann. 1971. Lipolytic activity of human gastric and duodenal juice against medium and longchain triglycerides. Gastroenterology. 60:1-15.

13. Tiruppathi, C., and K. A. Balasubramanian. 1982. Purification and properties of an acid lipase from human gastric juice. Biochim. Biophys. Acta. 712:692-697.

14. Hamosh, M., K. N. Sivasubramanian, C. Salzman-Mann, and P. Hamosh. 1978. Fat digestion in the stomach of premature infants. J. Pediatr. 93:674-679.

15. Hamosh, M., J. W. Scanlon, D. Ganot, M. Likel, K. B. Scanlon, and P. Hamosh. 1981. Fat digestion in the newborn. Characterization of lipase in gastric aspirates of premature and term infants. J. Clin. Invest. 67:838-846.

16. Liao, T. H., R. J. Buczek, N. R. Mehta, L. J. Grylack, P. Hamosh, and M. Hamosh. 1983. Fat digestion in the stomach: hydrolysis of formula triglyceride by premature infants. Clin. Res. 31:399A. (Abstr.)

17. Borgström, B. 1977. Digestion and absorption of lipids. Int. Rev. Physiol. 12:305-322.

18. Roy, C. C., M. Roulet, D. Lefebre, L. Chartrand, C. Lepage, and L. A. Fournier. 1979. The role of gastric lipolysis in fat absorption and bile acid metabolism in the rat. Lipids. 14:811-815.

19. Delachaume-Salem, E., and H. Sarles. 1970. Evolution en fonction de l'age de la sécrétion pancréatique humaine normale. Biol. GastroEnterol. 2:135-146.

20. Zoppi, G., G. Andreotti, F. Pajno-Ferrara, D. M. Njai, and D. Gaburro. 1972. Exocrine pancreas function in premature and full-term neonates. Pediatr. Res. 6:880-886.

21. Norman, A., B. Strandvik, and O. Ojamae. 1972. Bile acids and pancreatic enzymes during absorption in the newborn. Acta Pediatr. Scand. 61:571-576.

22. DeBelle, R. C., V. Vaupshas, B. B. Vitullo, L. R. Haber, E. Shaffer, G. G. Mackie, H. Owen, J. M. Little, and R. Lester. 1979. Intestinal absorption of bile salts: immature development in the newborn. J. Pediatr. 94:472-476.

23. Lester, R., R. A. Smallwood, J. M. Little, A. S. Brown, G. J. Piasecki, and B. T. Jackson. 1977. Fetal bile salt metabolism. The intestinal absorption of bile salt. J. Clin. Invest. 59:1009-1016.

24. Watkins, J. B. 1975. Mechanism of fat absorption and the development of gastrointestinal function. Pediatr. Clin. N. Am. 22:721730.

25. Watkins, J. B., P. Szczepanik, J. B. Gould, P. Klein, and R. Lester. 1975. Bile salt kinetics in premature infants. An explanation for inefficient lipid absorption. Gastroenterology. 69:706-713.

26. Park, R. W., and R. J. Grand. 1981. Gastrointestinal manifestations of cystic fibrosis: a review. Gastroenterology. 81:1143-1167.

27. Hadorn, B., G. Zoppy, D. H. Shmerling, A. Prader, I. McIntyre, and C. M. Anderson. 1968. Quantitative assessment of exocrine pancreatic function in infants and children. J. Pediatr. 73:39-50.

28. Weber, A. M., C. C. Roy, C. L. Morin, and R. Lasalle. 1973. Malabsorption of bile acids in children with cystic fibrosis. $N$. Engl. $J$ Med. 289:1001-1005.

29. Goodchild, M., G. Murphy, A. Howell, S. Nutter, and C. Anderson. 1975. Aspects of bile acid metabolism in cystic fibrosis. Arch Dis. Child. 50:769-777.

30. Watkins, J. B., A. M. Tercyak, P. Szczepanik, and P. D. Klein. 1977. Bile salt kinetics in cystic fibrosis: influence of pancreatic enzyme replacement. Gastroenterology. 73:1023-1028.

31. Harries, J. T., D. P. R. Muller, J. P. K. McCollum, A. Lipson, E. Roma, and A. P. Norman. 1979. Intestinal bile salts in cystic fibrosis. Arch. Dis. Child. 54:19-24.

32. Regan, P. T., J. R. Malagelada, E. P. Di Magno, and V. L. W. Go. 1979. Reduced intraluminal bile acid concentration and fat maldigestion in pancreatic insufficiency: correction by treatment. Gastroenterology. 77:285-289.

33. Roy, C. C., A. M. Weber, C. L. Morin, J. C. Combes, D. Nussle, A. Megevand, and R. Lasalle. 1977. Abnormal biliary lipid composition in cystic fibrosis. Effect of pancreatic enzymes. $N$. Engl. J. Med. 297:13011305.

34. Dutta, S. K., R. M. Russell, and F. L. Iber. 1979. Influence of exocrine pancreatic insufficiency on the intraluminal $\mathrm{pH}$ of the proximal small intestine. Am. J. Dig. Dis. 24:529-534.

35.Taussig, L. M., J. Kattwinkel, W. T. Friedwald, and P. A. di Sant 'Agnese. 1973. A new prognostic score and clinical evaluation system for cystic fibrosis. J. Pediatr. 82:380-390. 
36. Hamosh, M. Lingual lipase. 1984. In Lipolytic Enzymes. B. Borgström and $\mathrm{H}$. Brockman, editors. Elsevier BV, Amsterdam. In press. 37. Patton, J. S., M. W. Rigler, T. H. Liao, P. Hamosh, and M. Hamosh. 1982. Hydrolysis of triacyglycerol emulsions by lingual lipase: a microscopic study. Biochim. Biophys. Acta. 712:400-407.

38. Belfrage, $P$., and M. Vaughan. 1969. Simple liquid-liquid partition system for isolation of labeled oleic acid from mixtures with glycerides. J. Lipid Res. 10:341-344.

39. Rapport, M. M., and N. Alonzo. 1955. Photometric determination of fatty acid ester groups in phospholipids. J. Biol. Chem. 217:193-198.

40. Malagelada, J. R., G. F. Longstreth, W. H. J. Summerskill, and V. L. W. Go. 1976. Measurement of gastric function during digestion of ordinary solid meals in man. Gastroenterology. 70:203-210.

41. Snedecor, G. W., and W. G. Cochran. 1967. Statistical Methods. Sixth ed. The Iowa State University Press, Ames, IA. 59-62.

42. Vavrikova, H., and A. Krondl. 1965. Use of polyethylene glycol in investigations of the absorption of fat. Nature (Lond.). 208:293-294.

43. Sheldon, W. 1964. Congenital pancreatic lipase deficiency. Arch. Dis. Child. 39:268-271.

44. Rey, J., F. Frezal, P. Royer, and M. Lamy. 1966. L'absence congénitale de lipase pancréatique. Arch. Fr. Pediatr. 23:5-14.

45. Gooden, J. M., and A. K. Lascelles. 1973. Relative importance of pancreatic lipase and pregastric esterase in lipid absorption in calves 1-2 weeks of age. Aust. J. Biol. Sci. 26:625-633.

46. Ramsey, H. A., G. H. Wise, and S. B. Tove. 1956. Esterolytic activity of certain alimentary tissues from cattle in different age groups. J. Dairy Sci. 1312-1322.

47. Otterby, D. E., H. A. Ramsey, and G. H. Wise. 1964. Lipolysis of milk fat by pregastric esterase in the abomasum of the calf. J. Dairy Sci. 47:993-997.

48. Toothill, J., S. Y. Thompson, and J. D. Edwards-Webb. 1976. Studies on lipid digestion in the preruminant calf. The source of the lipolytic activity in the abomasum. Br. J. Nutr. 36:439-447.

49. Roulet, M., A. M. Weber, Y. Paradis, C. C. Roy, L. Chartrand R. Lasalle, and C. L. Morin. 1980. Gastric emptying and lingual lipase activity in cystic fibrosis. Pediatr. Res. 14:1360-1362.

50. Hamosh, M., and A. R. Hand. 1978. Development of secretory activity in serous cells of the rat tongue. Dev. Biol. 65:100-113.

51. Liao, T. H., P. Hamosh, and M. Hamosh. 1983. Gastric lipolysis in the developing rat: ontogeny of the lipases active in the stomach. Biochim. Biophys. Acta. 734:1-9.

52. Kopel, F. B., and G. J. Barbero. 1967. Gastric acid secretion in cystic fibrosis. Gastroenterology. 52:110. (Abstr.)

53. Bank, S., J. N. Marks, and A. Groll. 1966. Gastric acid secretion in pancreatic disease. Gastroenterology. 51:649-654.

54. Cox, K. L., J. N. Isenberg, and M. E. Ament. 1982. Gastric acid hypersecretion in cystic fibrosis. J. Pediatr. Gastroenterol. Nutr. 1:559565. 105.

55. Wolf, S. 1965. The Stomach. Oxford University Press, England.

56. Dutta, S. K., R. M. Russell, and F. L. Iber. 1979. Impaired acid neutralization in the duodenum in pancreatic insufficiency. Dig. Dis. Sci. 24:775-780.

57. Russell, A. M., H. Chang, and I. H. Rosenberg. 1974. Enhanced folic acid absorption in pancreatic insufficiency: assessment of folate binding capacity of pancreatic proteins. Gastroenterology. 66:873.

58. Russell, R. M., G. J. Dhar, S. K. Dutta, and I. H. Rosenberg. 1979. Influence of intraluminal $\mathrm{pH}$ on folate absorption. Studies in control subjects and patients with pancreatic insufficiency. J. Clin. Lab. Med. 93:428-436.

59. Fredrikzon, B., and L. Blackberg. 1980. Lingual lipase: an important enzyme in the digestion of dietary lipids in cystic fibrosis? Pediatr. Res. 14:1387-1390.

60. Di Magno, E. P., V. L. W. Go, and W. H. J. Summerskill. 1973. Relations between pancreatic enzyme outputs and malabsorption in severe pancreatic insufficiency. $N$. Engl. J. Med. 288:813-815.

61. Pope, J. L., J. C. McPherson, and H. C. Tidwell. 1966. A study of a monoglyceride-hydrolyzing enzyme in intestinal mucosa. J. Biol. Chem. 241:2306-2310.

62. Serrero, G., R. Negrel, and G. Ailhand. 1975. Characterization and partial purification of an intestinal lipase. Biochem. Biophys. Res. Commun. 65:89-99.

63. Negrel, R., G. Serrero, V. Fernandez-Lopez, and G. Ailhaud. 1976. Esterolytic activities of rat intestinal mucosa I. Characterization, cellular distribution, and subcellular localization of a glycerol-ester hydrolase. Eur. J. Biochem. 71:249-258.

64. Fernandez-Lopez, V., G. Serrero, R. Negrel, and G. Ailhaud. 1976. Esterolytic activities of rat intestinal mucosa. 2. Purification and properties of a glycerol ester hydrolase. Eur. J. Biochem. 71:259-270.

65. Graham, D. Y. 1977. Enzyme replacement therapy of exocrine pancreatic insufficiency in man. N. Engl. J. Med. 296:1314-1317.

66. Di Magno, E. P., J. R. Malagelada, V. L. W. Go, and C. G. Moertel. 1977. Fate of orally ingested enzymes in pancreatic insufficiency. N. Engl. J. Med. 296:1318-1322.

67. Meyer, J. H. 1977. The ins and outs of oral pancreatic enzymes. N. Engl. J. Med. 296:1347-1348.

68. Cox, K. L., J. N. Isenberg, A. B. Osher, and R. R. Dooley. 1979. The effect of cimetidine on maldigestion in cystic fibrosis. J. Pediatr. 94:488-492.

69. Hubbard, V. S., G. D. Dunn, and L. A. Lester. 1980. Effectiveness of cimetidine as an adjunct to supplemental pancreatic enzymes in patients with cystic fibrosis. Am. J. Clin. Nutr. 33:2281-2286.

70. Durie, P. R., L. Bell, W. Linton, M. L. Corey, and G. G. Forstner. 1980. Effect of cimetidine and sodium bicarbonate on pancreatic replacement therapy in cystic fibrosis. Gut. 21:778-786.

71. Boyle, B. J., W. B. Long, W. F. Balistreri, S. J. Widzer, and N. Huang. 1980. Effect of cimetidine and pancreatic enzymes on serum and fecal bile acids and fat absorption in cystic fibrosis. Gastroenterology. 78:950-953.

72. De Bienville, F., H. J. Neijens, J. Fernandes, M. Van Caillie, and K. F. Kerrebijn. 1981. Cimetidine as an adjunct to oral enzymes in the treatment of malabsorption due to cystic fibrosis. Acta Pediatr. Scand. 70:33-37.

73. Nassif, E. G., M. K. Younoszai, M. M. Weinberger, and C. M. Nassif. 1981. Comparative effects of antacids, enteric coating, and bile salts on the efficacy of oral pancreatic enzyme therapy in cystic fibrosis. J. Pediatr. 98:320-323. 